\title{
Reviving the Spirit of Gender Equality: Fatayat Nahdlatul Ulama between Idealism and Realization
}

\author{
Aprilian Ria Adisti ${ }^{1}$ \\ Institut Agama Islam Negeri (LAIN) Salatiga ${ }^{1}$ \\ aprilian@iainsalatiga.ac.id
}

\begin{abstract}
As the Muslim women's movement Nahdlatul Ulama, Fatayat NU has dedicated itself especially to reviving the spirit of gender equality in society. This study uses a descriptive qualitative research design that portrays basic cadre training as an effort to strengthen the spirit of gender equality in Fatayat NU cadres. This research is conducted at the Budossyan Village Hall, Tengaran District, Semarang Regency, which was attended by 50 Fatayat NU cadres. The data collection instruments are observation, interview and documentation. Realizing idealism in gender equality requires hard work from all elements. Fatayat NU is actively empowering women to reach gender equality in society even though in reality they still face many challenges and obstacles. The biggest challenge faced by Fatayat NU is how to fight the patriarchal culture that still dominates women roles in society. The results shows that the implementation of this training is successful in supporting Fatayat NU cadres to be more sensitive to issues of gender inequality by encouraging themselves to take an important role in society. Finally, it is concluded that the realization of idealism in reviving the spirit of gender equality in Fatayat NU still needs to be improved and evaluated periodically so that Fatayat NU cadres can become role models as agents of change in society in achieving gender equality.
\end{abstract}

Keywords: spirit; gender equality; Fatayat NU

\begin{abstract}
Abstrak
Sebagai gerakan perempuan muslim Nahdlatul Ulama, Fatayat NU telah mengabdikan diri khususnya dalam menghidupkan kembali semangat kesetaraan gender di masyarakat. Penelitian ini menggunakan desain penelitian kualitatif deskriptif yang memotret pelatihan kader dasar sebagai upaya untuk menguatkan semangat kesetaraan gender pada kader Fatayat NU. Penelitian ini dilakukan di Gedung Balai Desa Budossyan Kecamatan
\end{abstract}


JNUS: Journal of Nahdlatul Ulama Studies, Vol. 2, No. 1, Januari 2021: 17-33

Tengaran Kabupaten Semarang yang diikuti oleh 50 orang kader Fatayat NU. Instrumen pengumpulan data adalah observasi, wawancara dan dokumentasi. Mewujudkan idealisme dalam kesetaraan gender membutuhkan kerja keras dari semua elemen. Fatayat NU secara aktif memberdayakan perempuan untuk mencapai kesetaraan gender di masyarakat meski pada kenyataannya masih menghadapi banyak tantangan dan kendala. Tantangan terbesar yang dihadapi Fatayat NU adalah bagaimana melawan budaya patriarki yang masih mendominasi peran perempuan dalam masyarakat. Hasil penelitian menunjukkan bahwa penyelenggaraan pelatihan ini berhasil mendukung kader Fatayat NU untuk lebih peka terhadap isu-isu ketidaksetaraan gender dengan mendorong diri mereka untuk mengambil peran penting dalam masyarakat. Akhirnya disimpulkan bahwa perwujudan idealisme dalam menghidupkan kembali semangat kesetaraan gender di Fatayat NU masih perlu ditingkatkan dan dievaluasi secara periodik agar kader Fatayat NU dapat menjadi panutan sebagai agen perubahan masyarakat dalam mencapai kesetaraan gender.

Kata Kunci: spirit; kesetaraan gender; Fatayat NU

\section{INTRODUCTION}

Fatayat Nahdlatul Ulama (NU) is one of the largest Islamic women's organizations that really support women empowerment in Indonesia. Fatayat NU as young women of NU was established on April 24, 1950. This organization ideally is for NU women between the ages of 20 and 40 and has the main contribution for Indonesian women to improve their quality since this organization takes role as booster and activator (Yulianti, Izzah, \& Faculty, 2018). Fatayat NU initially focuses primarily on working in rural communities and pesantren, although over time, it also exists in urban communities and bring contribution in all aspects in society. One of the uniqueness of Fatayat NU is this organization still maintains the traditions of rural communities that are very close with patriarchy culture and underdeveloped in terms of social mobility coupled with the values in pesantren which is for some people is considered gender biased (Naziyah, 2015). On the other side, Fatayat NU also commits to adopt modern thinking about women's empowerment in this modern era. However, it also combines between pesantren's doctrine and emancipatory doctrine which is the part of the socio feminism movement, namely the 
existence of a relationship between social movements carried by women towards the social progress on society (Adhitia, 2015).

Revealing the dynamics of Fatayat NU as a Moslem women's movement in Indonesia, can be reflected from the system of social, ideology, politics and policy. The struggle of ideology, politics and policy of the authorities had been started since the pioneering phase in 1950 until 1953. Hamidah (2016) proposed that at that time, the "Three founder", Murthasiyah (Surabaya), Khuzaimah Mansur (Gresik), and Aminah (Sidoarjo) and several women had to struggle to convince the NU about the need to establish a women organization under NU. They did lobby to the high leaders' NU and charismatic Kyai to get support of this idea where it was not easy because they have to face the challenges that can weaken their spirit (Sukamto, 2017; Hidayat et al., 2020). One of the biggest challenge was about how to fight the patriarchal culture and the limited role of women that was restricted by their duty in the family. The patriarchal culture brings stigma that men at the top of the hierarchy, meanwhile women become second class (Sakina \& A., 2017). That is why, this culture became the barrier for Fatayat NU to be independent women organization at that time.

In addition, Fatayat NU was born inseparable from the spirit of nationalism from santri who lived at that time in realizing gender equality. This is very reasonable since the social, politics and culture conditions at that time was still discriminatory and insufficient beneficial for improving women's potential (Ahdiah, 2013; Syarifuddin, 2017). One of the impact of NU's birth in 1926 for supporting the potential and the women's movement is to develop a women's organization under NU organization to accommodate various programs and activities related to the interests of women, such as Muslimat NU, Fatayat NU and IPPNU (Hidayat et al., 2020). As a result, these Islamic women's movement is a discursive process, a process of producing meaning about gender, contructing identity, womanhood and collective selves (Qibtiyah \& Studies, 2009). Therefore, Fatayat NU with an autonomous institutional structure, has the flexibility to realize various ideas and carry out activities.

As the young women's branch of Nahdlatul Ulama, Fatayat NU has dedicated themselves especially in reaching the position of gender equality. This autonomous organization was legalized by NU in 1952 . 
JNUS: Journal of Nahdlatul Ulama Studies, Vol. 2, No. 1, Januari 2021: 17-33

There are six goals to be achieved by Fatayat NU; (1) raise and nurture young Muslim girls or women in the organization Fatayat NU, (2) raise the quality of education, instruction, skills, and expand knowledge for the benefit of religion, nation and state, (3) improve the role of Indonesian women in all aspect of life, religion, state and society, (4) enhance the mind and behavior (al-karimah morality) in daily life, (5) carry on business and has worked to support religious syiar, (6) build friendships with other organizations, especially youth and women organizations (Hamidah, 2016). In the 1980s, Fatayat NU showed their interest in conducting the intensive dialogue on feminist issues within their Islamic traditions. Furthermore, the women in Fatayat NU strengthened their cooperation with international organizations in the 1980s. Arnez (2010) stated this era is the new era for Fatayat NU since financially, this organization is supported by international donators, then, enable this organization to realize new programs over a wide area and more easily disseminate the publications. Thus, supported by international organizations, Fatayat NU strengthened the role concerning in defending women's rights and doing advocacy work. This is shown through the programs and achievements that have been realized in the last decade.

Theoretically, gender is a social construction that is formed to be embedded in a particular sex in a society (Adriana, 2009). In other word, gender is constructed by society and it is influenced by culture. Based on this definition, many Indonesian women still face social discrimination relating to gender injustice. Although, nowadays, women have played many roles in public sector, but in reality, social discrimination is still widely felt by women (Popp, et al., 2019). Gender bias, marginalization and stereotyping are the part of gender injustice. Meanwhile, Sulistyawan \& Nurfaidah (2020) proposed the concept of gender in the Islamic view must be understood from the nature and role of men and women. Both man and women have their respective roles and responsibilities in accordance with the command of Allah SWT. So, the concept of equality is not permissible for both men and women to bring down and humiliate each other, but they must complement each other's roles and responsibilities in line with the commands of Allah SWT. Regarding to this concept, no verse of Quran or hadist forbids women to take role in society. Meanwhile, Quran and hadist have numerously indicated that 
women are allowed to actively pursue various professional in society (Saifull et al., 2020; Glas et al., 2018) Moreover, Umar (1999) mentioned several aspects indicating the principle of gender equality is by referring to the positions of men and women in Quran, as follows; (1) women and men are both equal, as the servant, (2) women and men are the caliph one earth, the capacity of human as the caliph upon the earth, (3) women and men accept the initial agreement with God, and (4) Adam and Hawa involved actively in a Cosmic Drama. Thus, men and women have the same role and responsibility as the form of devotion to Allah SWT.

According to Buku Pengkaderan Fatayat Nabdlatul Ulama, Fatayat NU as a women's organization from Nahdlatul Ulama has a management structure from the central level to the bottom level. This organization has the mission, namely "Building critical awareness to women in order to achieve gender equality and justice through strengthening human resources and community empowerment". Thus, to achieve this mission, Fatayat NU has strategies that are sourced from the Khittah Nadhliyah through organization. Actually, in Khittah NU is written that organization is a tool to achieve the goals of organization, as well as Fatayat NU through the vision and mission. Thus, all the works done by cadres / Fatayat NU members are actions that have been designed with directed and organized rather than spontaneous actions or sporadic. Nur Agustin (2016) mentioned through Fatayat NU, it is expected that the women will be able to develop critical awareness especially in public sector. This awareness is also transmitted to community with the hope that Fatayat NU can establish the culture of gender equality in society. This hope is realized by Fatayat NU by providing training skills for cadres through basic cadre training.

Several studies have highlighted the effort of Muslim feminist movements to reinterpreting the values of gender equality based on Islamic sources. The study from Arnez (2010) entitled Empowering Women through Islam: Fatayat NU between Tradition and Change revealed that Fatayat NU has declared women's empowerment as one of its major aims and has used gender-just interpretations of Islamic sources to legitimate this goal. In addition, a study from Mulia (2013) entitled Hukum Islam dan Dinamika Feminisme dalam Organisasi Nabdlatul Ulama' exposed that Nahdlatul Ulama consciously and courageously supports the 
JNUS: Journal of Nahdlatul Ulama Studies, Vol. 2, No. 1, Januari 2021: 17-33

implementation of women empowerment significantly. Then, NU also opens up to develop space for an expanded discussion about the role of women in society as the way to counter discrimination for women and gender mainstreaming bias even in the area of Islamic law (fiqh). On the contrary, the study from Nuryartono \& Pataporn Sukontamarn (2010) entitled Islamic Women's Organizations in Indonesia: Characteristics, Activities, and Government Funding showed organizations which declare that they conduct activities related to women's empowerment such as Fatayat NU face problems to get government funding compared to those that do not have activities related to women's empowerment.

Another previous research from Yulianti et al., (2018) entitled Nahdlatul Ulama Middle Class Woman and Civil Society Consolidation in Sidoarjo Regency. The result showed that all roles of Fatayat in cultures, religion, community social justification, language education, health service, consumer protection, environment, economy development, minority rights, media, economy justification, and politics sectors are all well implemented. Furthermore, a study entitled Bangkit dari Ketertindasan (Studi atas Pemikiran Kesetaraan Gender Fatayat NU) from Safri (2012) revealed that Fatayat NU brings the vision and mission of liberating women from all forms of injustice and abuse against women. For Fatayat NU, all forms of violence and injustice against women are formed from culture and customs, so that the legitimacy of religious texts is a form of misunderstanding of the religious text itself. Meanwhile, the study from Agustin (2016) entitled Partisipasi Fatayat Nabdlatul Ulama Sidoarjo dalam Pendidikan Politik Bagi Perempuan described the leadership participation of Head Brach Fatayat NU Sidoarjo in political education for women as the way to support gender equality in real action. Therefore, this article has novelty aspect compared to the previous research since this article looks at the way in which Fatayat NU utilizes Islamic values as a strategy to promote gender equality. Moreover, this article also aims at revealing and exposing basic cadre training as an effort to equip the values of gender equality that is organized by the Fatayat NU, the branch of the Tengaran district on 11 March 2021.

This research applied descriptive qualitative research design. The goal of this research design is to describe a phenomenon and its characteristics. This research is more concerned with what rather than 
how or why something has happened. Therefore, observation and survey tools are often used to gather data (Gall, Gall, \& Borg, 2007). In addition, qualitative research, however, is more holistic and often involves a rich collection of data from various sources to gain a deeper understanding of individual participants, including their opinions, perspectives, and attitudes (Nassaji, 2015). This study portrays basic cadre training as an effort to equip the values of gender equality that is organized by Fatayat NU. The research was conducted at Budossyan Village Hall, Tengaran District, Semarang Regency, March 11, 2021. This training was attended by 50 members of Fatayat NU. The data collection instruments were observation, interview and documentation. Qualitative data were collected through focus group and semi-structured interviews with the leader of Fatayat NU, the branch of the Tengaran district. The data were analyzed qualitatively by progressively exposing the basic cadre training from the planning until realization. Another interesting qualitative component of this study was that further follow-up interviews were also arranged to the head of Fatayat NU to check, confirm and clarify about the implementation of basic cadre training relating to introducing gender equality values. Systematically, the steps of the research also stated in the following scheme:

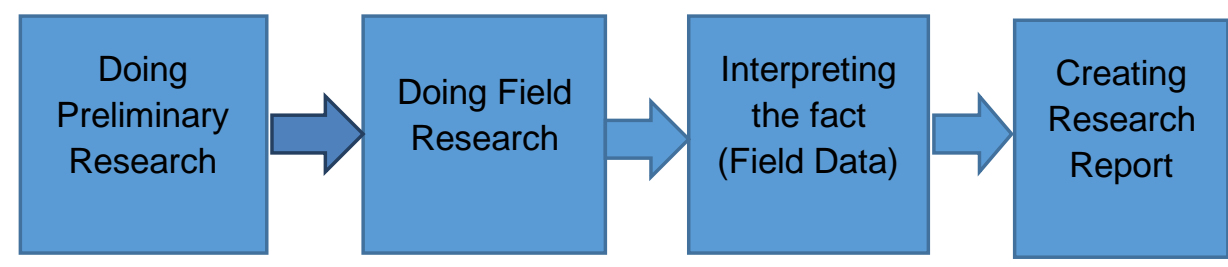

Figure 1. Steps of conducting the research.

Preliminary research was the first step in conducting this study. This step was done to get pre-information about Fatayat NU which taken from the document review, literature review, observation and documentation before conducting field research. Not only about the Fatayat NU, but the researcher also got the information about the panning of implementation basic cadre training from the preparation from the committee, handout, and rundown the activity. In this step, some data compiled to strengthen the next step of the research. Then in doing field research, the researcher observed the implementation of basic cadre training of Fatayat NU 
JNUS: Journal of Nahdlatul Ulama Studies, Vol. 2, No. 1, Januari 2021: 17-33

specifically in terms of introducing gender equality values to the member of Fatayat NU who joined this activity. To strengthen the result of observation, the researcher also actively did interview to the leader of Fatayat NU about the implementation of basic cadre training from gender perspective side. After doing field research, then the researcher collected and interpreted the data to get findings. Furthermore to increase the credibility and validity of research findings, the researcher did theoretical triangulation by combining theories, methods or observers in a research study. While, creating research report is the last step after the findings have been analyzed.

\section{RESULTS AND DISCUSSIONS}

Fatayat NU as the young women's branch of Nahdlatul Ulama has committed to spread the idealism in countering gender bias and discrimination in society through empowering women and giving awareness about gender equality values starting from basic cadre training. This activity is the part of resistance towards inequality gender such as labeling and stereotyping, marginalization, sexual harassment and unfair gender role in politics, education, economic, religious, and others in society. Quoted from Modul Latihan Kader Dasar (LKD) Fatayat NU and Buku Pengkaderan Fatayat Nabdlatul Ulama, basic cadre training is a forum of cadre held at the branch and / or sub-branch level of Fatayat NU. This training is held in order to accept new members and cadres as a medium of introduction in instilling values, identity, character and ideology of Fatayat NU. There are two objectives of implementing basic cadre training; first is in general objective and second is in specific objective. In general, this training is expected to mold cadres who have Islamic insight, militancy and loyalty, a sense of belonging and high responsibility to this organization. Meanwhile, specifically, there are five main goals; (1) creating a militant and committed cadre toward the organization, (2) developing the values of national insight, (3) developing Ahlusunnah Wal Jamaah values, (4) reviving awareness of the position of women as God's creatures, and (5) molding cadres who have organization, management, leadership and communication skills. At the end of basic cadre training, it is expected that participants have the following characters: 
a. Trust. Cadres must be able to be trusted in running the task of the organization. Therefore, cadres must always uphold honesty and truthfulness.

b. Have a militant soul. It means that all cadres must have loyalty to the organization in the right sense. This loyalty can be assessed based on their deep commitment in accordance to the vision and mission of the organization.

c. Pioneering (role model) is needed because of cadres is an asset of nation and organization. If the cadres have the spirit of being good role model, so they will be able to change the condition of the nation to face multidimensional problems.

d. Creative and dynamic. Cadres must be ready to accept change positively and creatively. Thus, cadres must be creative and always try to find solutions for any problems that arise because of change

e. Have the ability to share motivation. Cadres are alive in the middle of a pluralistic society. If they are in a position as the leader in society, they must be able to motivate the members organizations and community.

f. Build a network. This skill is tremendously needed to strengthen the organization in institution, finance, solidarity etc both in internal organization and external organizations.

g. Have ability to solve the problems and being innovative. A cadre must able to solve the problems innovatively. They must have experience to enrich his knowledge in problem solving.

h. Independent. Cadres are expected to be independent in running organizational activities and struggeling for basic values organizational.

i. Have great knowledge. By having knowledge, hopefully cadres can build a culture of thinking and be a director in considering rationality and reality. They must have wise attitude and responsive when facing various kinds of social problems.

Overall, this basic cadre training uses an approach activeparticipatory. Basic training framework use is based on the principle of andragogy. The principle of andragogy requires a role active all participants in the training. Participants are expected to share practical 
JNUS: Journal of Nahdlatul Ulama Studies, Vol. 2, No. 1, Januari 2021: 17-33

experiences through sharing experiences, recognizing, identifying, analyze, conclude and reflect on it to be new knowledge or experience and practical work / exercises. Sharing experiences from participants are used as the basis of reference for each subject. Participants are assumed not as an "empty bottle" with no experience but they have very valuable experiences. Meanwhile, recognizing and identifying is a process of knowing and identifying good experiences from one participant to others. The process of recognizing and identifying requires the principle of openness, honesty and the ability to accept the diversity of experiences. Then, analyzing is a critical process in which they can receive diversity in a community. There is also an analytic process that requires criticism from participants to identify experiences. The process of analyzing is the process of testing the truth (critical) of experiences. Practical work or practice exercises in basic cadre training is the most important stage. Here each participant will combines cognitive and affective elements in a practice of a particular subject. Practical work will be done individually in small or large group.

In addition, the participants of basic training cadres Fatayat NU must have the following criteria: (1) every Indonesian woman except those who have followed basic training cadres Fatayat NU before, (2) aged 20 to 40 years old and want to be cadre of Fatayat NU, (3) The number of participants consists of 30-40 people. If the participants more than 40 people, it should be divided into two or more classes and implemented periodically. The material presented in basic cadre training is based on the following chart:

\begin{tabular}{|c|l|c|}
\hline No & \multicolumn{1}{|c|}{ Material } & Time allocation \\
\hline 1. & Introduction & 120 minutes \\
\hline 2. & Study contract & 120 minutes \\
\hline 3. & Aswaja & 120 minutes \\
\hline 4. & Ke-NU-an & 120 minutes \\
\hline 5. & Ke-Fatayatan & 120 minutes \\
\hline 6. & Social Analysis and Gender & 120 minutes \\
\hline 7. & Management and organization & 120 minutes \\
\hline 8. & Leadership & 120 minutes \\
\hline
\end{tabular}




\begin{tabular}{|c|l|l|}
\hline 9. & Communication & 120 minutes \\
\hline 10. & Tim work & 120 minutes \\
\hline 11. & Society empowerment & 120 minutes \\
\hline 12. & RTL & 120 minutes \\
\hline 13. & Evaluation and closing & 120 minutes \\
\hline
\end{tabular}

Figure 2. Materials in basic cadre training Fatayat NU

In reviving awareness about gender equality to the material of social and gender analysis, there are several objectives to be achieved, namely; (1) participants are able to understand the processes, causes and impacts of social change, (2) participants are able to identify processes of social change in positive and negative side, (3) participants will understand the meaning of gender and its role that happens in society and (4) participants are able to distinguish gender equality and injustice viewed from Islamic perspective. Furthermore, the sub topics discussed in the social analysis and gender are the theoretical framework of the processes and causes in social transformation, the factors of causing social change, the concept of gender roles and functions in family life and society, and the factors of causing gender inequality and its impact viewed from Islamic perspective.

Based on observations did in field research, basic cadre training activities carried out by Fatayat NU Tengaran district, March 11, 2021, found several facts. The training did effectively and systematically and was attended by 50 participants. This training also invited experts who have background that is adjusted with the materials on the training. Specifically, on the material that related to social analysis and gender, the committee invited an expert from Pusat Studi Gender dan Anak (PSGA) IAIN Salatiga to present the material. At the beginning of the training, the speaker presented theories about gender and nature (kodrat) differences from Islamic perspective, gender discrimination that occurs in society and how to overcome it, and the roles of women in society. This activity also support the theory from Sulistyawan \& Nurfaidah (2009) that mentioned women should understand the differences between gender and nature (kodrat) from Islamic perspective so they can identify which one that allow 
JNUS: Journal of Nahdlatul Ulama Studies, Vol. 2, No. 1, Januari 2021: 17-33

to be done or not as a Muslimah relates to their duties and responsibilities in society.

Then the activity continued with group discussion to analyze the issues related to gender inequality. At this moment, participants gave their views and opinions on the issues being discussed. During this moment, the participants also exchanged their thoughts and experiences and drew conclusions about the values of gender equality that must be achieved as a cadre of Fatayat NU. The interaction between speaker and participants was also good. The training method was considered as attractive method since it can stimulate participants to be active in discussion activities when talk about the issues of gender inequality in society. The flow of the training activities was going well. There were sessions of listening the material, answering questions, discussing the issues of gender equality from Islamic perspective, drawing conclusion and reflecting on the material. At the end of the training, each participant reflected on the material they had discussed together. Some of the participants even shared their reflections in front of the stage. All the results of the participants' reflections show positive views and opinions so this indicates that this training is able to strengthen their awareness of how to become agents of change in fighting gender inequality in society. This fact also strengthen the finding from Safri (2012) that mentioned Fatayat NU spread the vision and mission of liberating women from all forms of gender inequality by empowering women and giving awareness of gender equality values in society through education. Below is the documentation during the implementation of basic cadres training Fatayat NU Tengaran district, 11 March 2021. 


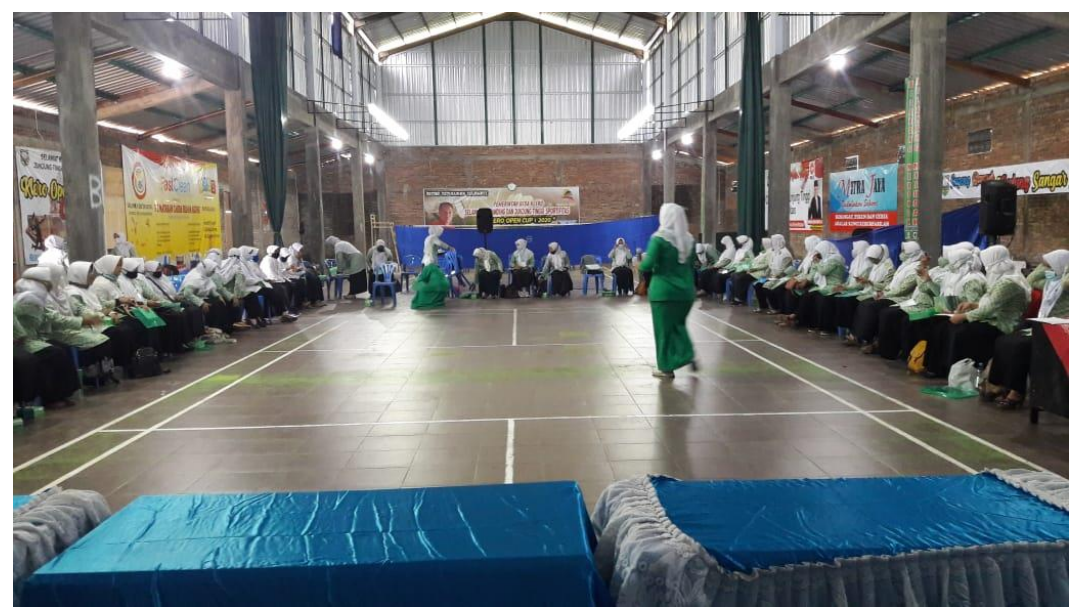

Figure 3. Documentation of basic cadre training Fatayat NU kecamatan Tengaran

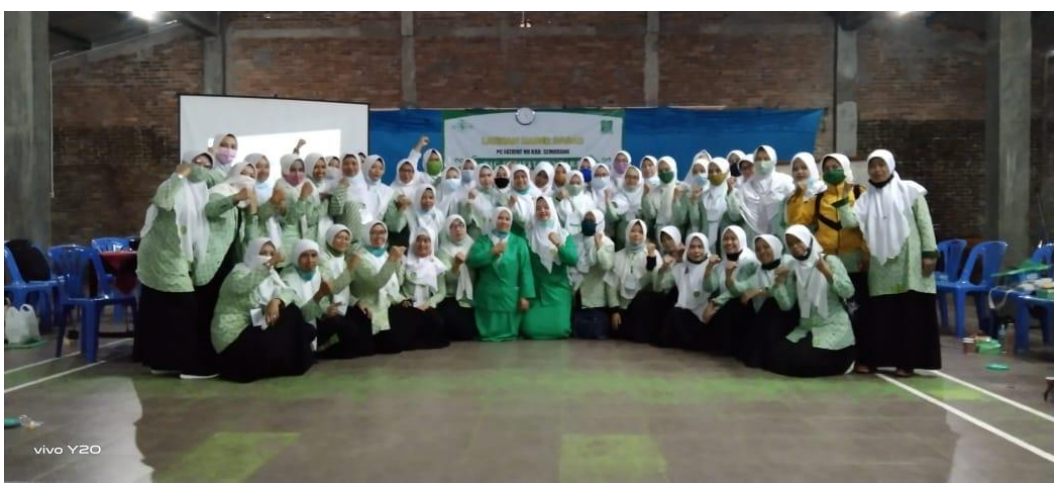

Figure 4. Documentation of basic cadre training Fatayat NU kecamatan Tengaran

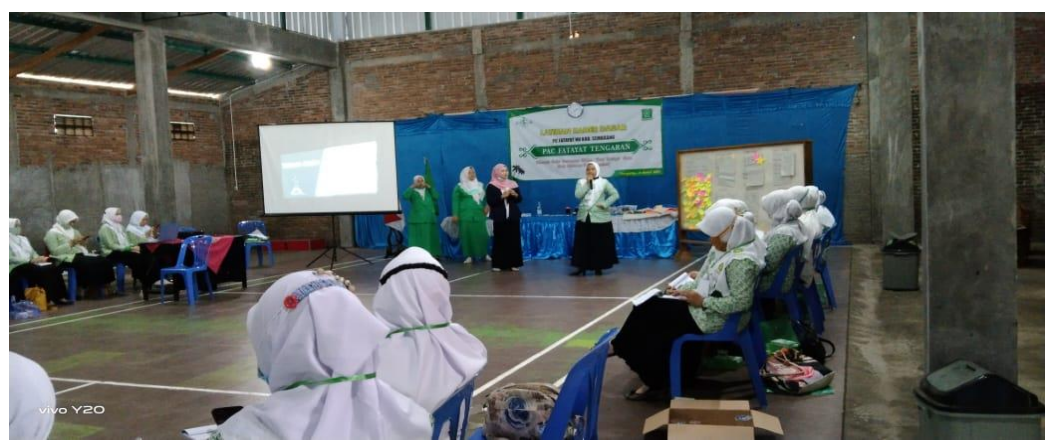

Figure 4. Documentation of basic cadre training Fatayat NU kecamatan Tengaran 
JNUS: Journal of Nahdlatul Ulama Studies, Vol. 2, No. 1, Januari 2021: 17-33

Supporting the result of the observation, the interview was also conducted to the head of Fatayat NU kecamatan Tengaran in order to strengthen the finding. Below were the transcriptions of the interview.

"The benefit of providing awareness about gender equality for cadres of Fatayat $N U$ is to increase the understanding of concept gender from Islamic perspective. Actually, Islam has never discriminated against women. It is seen from the literacy, Qur'an and hadist which when it is analyzed deeply, there are many interpretations of tafsir that have been contaminated with the construction of a patriarchal in society, "said the head of Fatayat NU kecamatan Tengaran, April 4, 2021 through voice note of whatsApp application. This statement was an affirmation of many issues concerning gender inequality that must be clarified from an Islamic perspective. She also emphasized that the interpretations of tafsir that have developed in society mostly are not sourced from the Qur'an and hadist and they are only constructed by culture in society.

"Why are we aiming at this benefit because there are many women in Fatayat NU whose space is limited by thoughts, in this case is their husbands who limit their activities, for example in joining training which takes time from morning to evening. There are many of them still do not get permission from their husbands because of domestic reasons. This case must be the priority to be solved. If this case is allowed to continue in today's era, women will be increasingly isolated and subordinated. The cadres of Fatayat NU actually have high enthusiasm towards gender issue but when we see the reality, there are many women still feel fear to expose beliefs about the values of gender equality because they are influenced by the mindset of their husband and society about the role of women who should only focus on domestic area that finally also influence their beliefs. They are actually want to take a part in many aspects but sometimes they are limited by the stigmas inherent in the mindset of couples, society and themselves, "said the leader of Fatayat NU kecamatan Tengaran, April 4, 2021 through voice note of whatsApp application. This statement showed that there were many cases that happened to the member of Fatayat NU who still have to face gender discrimination in relation to their duty as women in domestic aspect. Furthermore, this statement also contained awareness to overcome this problems, especially for the members of Fatayat NU by empowering them to be brave in countering gender discrimination.

"Gender workshop activities are usually long-term activities that have actually been listed in the agenda of work Fatayat NU. However, sometimes it is indeed 
constrained by many incidental things such as today we face pandemic covid 19 which really limits several agendas, one of which is a workshop on gender equality. Actually Fatayat also has LKP3A which stands for Consultation Institute for Women's Empowerment and Child Protection, but indeed the function of this institution has not been optimal because many friends from grassroots choose to let this the situation when receiving gender biased or gender inequality, "said the leader of Fatayat NU kecamatan Tengaran, April 4, 2021 through voice note of whatsApp application. This statement had three interpretations, namely (1) Fatayat NU realized that there was still a lot of gender discrimination happened to women, especially their cadres, (2) there are still many Fatayat NU cadres who choose to let a situation of gender discrimination happen to them, and (3) the activities related to women's empowerment programs are not yet optimal in order to raise awareness of gender equality among Fatayat NU members.

The results of the interview reveal facts about the challenges and obstacles faced by Fatayat NU in realizing their idealism on the issue of gender equality in society. This findings also strengthen the study from Sakina \& A., (2017) about the biggest challenge of Fatayat NU in realizing gender equality is how to fight the patriarchal culture and the limited role of women that was restricted by their duty in the family. This culture influence the stigma that men at the top of the hierarchy, meanwhile women should only focus on domestic area. So, it can be concluded that Fatayat NU's idealism in realizing the spirit of gender equality still requires hard effort because it is related to the obstacles that must be faced, especially in relation to patriarchal culture in society. Then, the implementation of the Fatayat NU basic cadre training, is considered as an effort to empower women and increase their awareness of the values of gender equality that must be achieved. This training activity also needs to be continued periodically in order to obtain optimal results.

\section{CONCLUSION}

Realizing idealism to achieve gender equality requires hard work. Fatayat $\mathrm{NU}$ is a women's organization that actively revives the spirit of gender equality in society even though in reality it still faces many challenges and obstacles. The integration of social and gender analysis materials in the basic training of Fatayat NU cadres is an effort to realize the idealism of 
JNUS: Journal of Nahdlatul Ulama Studies, Vol. 2, No. 1, Januari 2021: 17-33

gender equality values. The implementation of this training succeeded in stimulate the Fatayat NU cadres to be more sensitive to the issue of gender inequality by empowering themselves to take an important role in society. Finally, it was concluded that the realization of idealism in reviving the spirit of gender equality in Fatayat NU still needs to be improved and evaluated periodically so that Fatayat NU cadres can become role models as agents of change in society in achieving gender equality.

\section{REFERENCES}

Adhitia, D. (2015). Gerakan Sosiofeminisme dalam Pemberdayaan Perempuan Nahdhatul Ulama. Universitas Negeri Jakarta.

Adriana, I. (2009). Kurikulum Berbasis Gender (Membangun Pendidikan yang Berkesetaraan). Tadris, 4(1).

Ahdiah, I. (2013). Peran-peran Perempuan dalam Masyarakat. Jurnal Academica, 05(02), 1085-1092.

Arnez, M. (2010). Empowering women through Islam: Fatayat NU between tradition and change. Journal of Islamic Studies, 21(1), 59-88. https://doi.org/10.1093/jis/etp025

Glas, S., Spierings, N., \& Scheepers, P. (2018). Re-Understanding Religion and Support for Gender Equality in Arab Countries. Gender and Society, 32(5), 686-712. https://doi.org/10.1177/0891243218783670

Hamidah, H. (2016). Indonesian Islamic Movement of Women: a Study of Fatayat Muslimat $\mathrm{Nu}$ (1938-2013). MIQOT: Jurnal Ilmu-Ilmu Keislaman, 40(1), 162-174. https://doi.org/10.30821/miqot.v40i1.260

Hidayat, W. N., Syahir, A. A., \& Maliana, D. (2020). Perkembangan Fatayat $\mathrm{Nu}$ Kabupaten Subang Dalam Bidang Kaderisasi Periode 2015-2020. Historia Madania, 4(2), 335-354.

Mulia, M. (2013). Hukum Islam Dan Dinamika Feminisme Dalam Organisasi Nahdlatul Ulama'. Al-Abkam, 23(1), 37. https://doi.org/10.21580/ahkam.2013.23.1.72

Nassaji, H. (2015). Qualitative and descriptive research: Data type versus data analysis. Language Teaching Research, 19(2), 129-132. https://doi.org/10.1177/1362168815572747

Naziyah, N. and S. D. I. S. R. (2015). Fatayat NU dalam Aspek 
Kemasyarakatan di Surabaya Tahun 1959-1967. VERLEDEN : Jurnal Kesejarahan, 3(2), 175-182.

Nur Agustin, M. (2016). Partisipasi Fatayat Nahdlatul Ulama Sidoarjo Dalam Pendidikan Politik Bagi Perempuan. Kajian Moral Dan Kewarganegaraan, 3(4), 1073-1088.

Nuryartono, N., \& Pataporn Sukontamarn. (2010). Islamic Women's Organizations in Indonesia: Characteristics, Activities, and Government Funding. 18th Biennial Conference of the Asian Studies Association of Australia in Adelaide, 5-8 July 2010.

Popp, A. L., Lutz, S. R., Khatami, S., van Emmerik, T. H. M., \& Knoben, W. J. M. (2019). A Global Survey on the Perceptions and Impacts of Gender Inequality in the Earth and Space Sciences. Earth and Space Science, 6(8), 1460-1468. https://doi.org/10.1029/2019EA000706

Qibtiyah, A., \& Studies, A. (2009). Indonesian Muslim Women and Gender Equality Movement. Journal of Indonesian Islam, 03(01), 49-58.

Safri, A. N. (2012). Bangkit dari Ketertindasan (Studi atas Pemikiran Kesetaraan Gender Fatayat NU). Musawa, 11(1).

Saiful, T., Yaswirman, Yuslim, \& Fendri, A. (2020). Gender Equality Perspective and Women Position in Islam. 413(Icolgis 2019), 197-200. https://doi.org/10.2991/assehr.k.200306.212

Sakina, A. I., \& A., D. H. S. (2017). Menyoroti Budaya Patriarki Di Indonesia. Share: Social Work Journal, 7(1), 71. https://doi.org/10.24198/share.v7i1.13820

Sukamto. (2017). Analisis Produktivitas Perempuan Fatayat NU. Jurnal Ekonomi Islam, 8, 277-302.

Sulistyawan, A. Y., \& Nurfaidah, S. S. (2020). Gender Construction in Islamic Perspective. Ijtimäiyya: Journal of Muslim Society Research, 5(1), 47-56.

Syarifuddin, A. (2017). Peran Strategis Kaum Perempuan dalam Mewujudkan Masyarakat Religi. An Nisa'a, 12(1), 21-32.

Yulianti, I., Izzah, U., \& Faculty, P. (2018). Nabdlatul Ulama Middle Class Woman And Civil Society Consolidation In Sidoarjo Regency. 8(4), 386-387. 